\title{
The Fekete-Szegö functional for a subclass of analytic functions associated with quasi-subordination
}

\section{H. M. SRIVASTAVA ${ }^{1,2}$, SAQib Hussain ${ }^{3}$, Alia RAZIQ ${ }^{3}$ and MoHSAn RAZA ${ }^{4}$}

\section{ABSTRACT.}

In the present paper, we introduce and investigate the Fekete-Szegö functional associated with a new subclass of analytic functions, which we have defined here by using the principle of quasi-subordination between analytic functions. Some sufficient conditions for functions belonging to this class are also derived. The results presented here improve and generalize several known results.

\section{REFERENCES}

[1] Altınkaya, Ş. and Yalçın, S., Coefficient estimates for two new subclasses of bi-univalent functions with respect to symmetric points, J. Funct. Spaces, 2015 (2015), Article ID 145242, 1-5

[2] Altınkaya, Ş. and Yalçın, S., On a new subclass of bi-univalent functions of Sakaguchi type satisfying subordinate conditions, Malaya J. Math., 5 (2017), 305-309

[3] Fekete, M. and Szegö, G., Eine Bemerkung Über Ungerade Schlichte Funktionen, J. London Math. Soc., 8 (1933), No. 2, 85-89

[4] Goyal, S. P. and Goswami, P., Certain coefficient inequalities for Sakaguchi type functions and applications to fractional derivative operator, Acta Univ. Apulensis, 19 (2009), 159-166

[5] Keogh, F. R. and Merkes, E. P., A coefficient inequality for certain classes of analytic functions, Proc. Amer. Math. Soc., 20 (1969), 8-12

[6] Mohammad, M. H. and Darus, M., Fekete-Szegö problems for quasi-subordination classes, Abstr. Appl. Anal., 2012 (2012), Article ID 192956, 1-14

[7] Nehari, Z., Conformal Mapping, McGraw-Hill Book Company, New York, 1952

[8] Nunokawa, M., Obradović, M. and Owa, S., One criterion for univalency, Proc. Amer. Math. Soc., 106 (1989), 1035-1037

[9] Obradović, M., A class of univalent functions, Hokkaido Math. J., 2 (1988), 329-335

[10] Owa, S., Sekine, T. and Yamakawa, R., On Sakaguchi type functions, Appl. Math. Comput., 187 (2007), 356-361

[11] Robertson, M. S., Quasi-subordination and coefficient conjectures, Bull. Amer. Math. Soc., 76 (1970), 1-9

[12] Sakaguchi, K., On a certain univalent mapping, J. Math. Soc. Japan, 11 (1959), 72-75

[13] Sharma, P. and Raina, R. K., On a Sakaguchi type class of analytic functions associated with quasi-subordination, Comment. Math. Univ. St. Paul., 64 (2015), 59-70

[14] Srivastava, H. M., Mishra, A. K. and Das, M. K., The Fekete-Szegö problem for a subclass of close-to-convex functions, Complex Variables Theory Appl., 44 (2001), 145-163

[15] Tang, H., Srivastava, H. M. and Deng, G.-T., Some families of analytic functions in the upper half-plane and their associated differential subordination and differential superordination properties and problems, Appl. Math. Inform. Sci., 11 (2017), 1247-1257

\section{${ }^{1}$ Department of Mathematics and Statistics \\ UNIVERSITY OF VICTORIA \\ VICTORIA, BRITISH COLUMBIA V8W 3R4, CANADA}

Received: 26.05.2017; In revised form: 15.01.2018; Accepted: 22.01.2018

2010 Mathematics Subject Classification. 30C45; 30C50.

Key words and phrases. Analytic functions, Univalent functions, Principles of subordination and quasisubordination, Fekete-Szegö functional, Taylor-Maclaurin coefficients, Schwarz function.

Corresponding author: H. M. Srivastava; harimsri@math.uvic.ca 
${ }^{2}$ Department of Medical Research

China MedicAl University HOSPITAL

China Medical University

TAICHUNG 40402, TAIWAN, RePUbliC OF ChinA

E-mail address: harimsri@math.uvic.ca

\section{${ }^{3}$ Department of Mathematics}

COMSATS INSTITUTE OF INFORMATION TECHNOLOGY

ABBOTTABAD, PAKISTAN

E-mail address: saqib_math@yahoo.com

E-mail address: aliyaraziq93@gmail.com

${ }^{4}$ Department of Mathematics

GOVERNMENT COLLEGE UNIVERSITY

FAISALABAD, PAKISTAN

E-mail address: mohsan976@yahoo.com 